\title{
Review on Identification of Major Infection Site and Disease Progression Pathway for Early Detection of Novel Corona Virus (Covid-19)
}

\author{
Manohari M.Wickramaratchi ${ }^{*}$, Alexander Pieris ${ }^{1}$, Shehan W.S.A.J.Fernando ${ }^{1}$ \\ ${ }^{1}$ Life Sciences Research Centre Sri Lanka, Subuthipura, Battaramulla 10120, Sri Lanka \\ Correspondence should be addressed to Manohari M.Wickramaratchi; \\ researchhydroscience@gmail.com : ORCID ID 0000-0003-3419-8628 \\ Keywords: Review, Methodology, Hypothesis, Open Science, Open Data, Life Sciences, Medical \\ \& Health sciences, Covid-19, Novel Corona Virus
}

\begin{abstract}
The Novel Coronavirus disease, COVID-19, is a new highly contagious infection, transmitted from human to human of pandemic proportion. The number affected is increasing dramatically, without specific therapy nor vaccination available. The major challenges for its epidemiological control include the prolonged incubation period without symptoms and its ability to transmit the disease by both symptomatic and asymptomatic. This review is to bring an awareness to the scientific and medical community a major route of infection during incubation period, suggesting a new diagnostic approach to be adopted. Exploration of this study may unfold a unique approach to the early detection and clinical management well before its progression to severe disease manifestation. We highlight the importance of evaluating pancreatic function, hepatocellular changes and gastrointestinal lining to enable early diagnosis of the disease.
\end{abstract}

\section{Introduction}

In December 2019, a cluster of acute respiratory illness, now known as novel coronavirus (2019 nCoV)-infected pneumonia (NCIP) occurred in Wuhan, China [1-5] In January 2020, and China National Health Commission confirmed human to human transmission of Covid-19 [6, 7]. The disease has rapidly spread from Wuhan to other areas of the globe as a highly infectious disease and recorded in more than 183 countries. As of 8th April 2020, total of 1,464,852 have been infected, 85,397 deaths recorded and 351,105 has recovered according to the Systems Science and Engineering at John Hopkins University, USA.

The main concern is where the Covit-19 propagates inside the human body before it expresses symptoms in the respiratory tract. This review highlights a major site of disease proliferation leading to biochemical changes that cause internal tissue damages. We highlight the importance of investigating the pancreatic enzyme profiles, hepatocellular and gastrointestinal changes, based on organ dysfunction observed within the first 10 days of infection during the first phase of the incubation period. 
The demographic, clinical and biological characteristics abnormalities associated with COVID-19 have been described. More specifically, we have reports on the sequence of symptoms, incubation period, biological and CT abnormalities and some treatment outcomes $[8,9,10,14,15]$.

Additionally, there are reports of data on virus shedding, with studies on the dynamics of viral load in sputum, urine, throat swab and stool samples in symptomatic and asymptomatic individuals. Viral shedding in patients who recovered is also described $[8,9,14,15]$.

According to the World Health Organization (WHO), the most common symptoms of Covid-19 are fever, tiredness and a dry cough. Some patients may also have a runny nose, sore throat, nasal congestion and dyspnea at a median of 8 days after symptom onset [28]. Many patients reported gastrointestinal symptoms such as diarrhea, vomiting and abdominal pain $[8,10,23]$. Studies have identified the SARS-CoV-2 RNA in stool specimens of infected patients, and its viral receptor angiotensin converting enzyme 2 (ACE2) was found to be highly expressed in gastrointestinal epithelial cells [9,23]. Faeces of Covid-19 patients were found to be highly infectious [27].

Some reported losing the sense of taste and/or smell [19]. About $80 \%$ who contracted Covid-19 experienced a mild infection and recovered without needing any special treatment $[14,15]$. Those who have a serious form of Covid-19 may rapidly progress to acute respiratory distress syndrome, coagulation dysfunction and septic shock [35].

The main challenge to disease control globally is the increasingly reported asymptomatic individuals who can transmit SARS-CoV-2 infection [16, 17].

Assessment of the viral loads in symptomatic patients have shown this peaks within the first few days of symptoms, and also that individuals can have a similarly high viral load without showing any symptoms [18].

Eight strains of the Corona Covid-19 virus are currently identified circulating around the globe, which scientists are tracking by their genetic footprints [25]. Laboratories around the world are rapidly sequencing the genomes of virus samples taken from people infected with COVID-19. The information is uploaded to NextStrain.org website, that shows how the virus is migrating and splitting into similar but new subtypes. Genetic sequence reveals the virus as unique microscopic fragments to the origins of its original strain, how it behaves as it mutates and which strains are turning into conflagrations while others are dying due to quarantine measures [25]. 


\section{a. Implications of the available evidence}

Most commonly cited issue of Covid-19 is based with the status of bilateral lung abnormalities and pneumonia, where the disease process appears to start as its first site of Covid-19 virus invasion that subsequently progresses into a severe condition. This observation has hindered identifying true nature of the disease.

Study related to the first case of Coronavirus in the United States reported, no evidence of infiltrates or abnormalities in the chest radiography until the $8^{\text {th }}$ day of symptoms [35]. At this stage the total number of days including incubation period approximately 18-21 and patient suffered leukopenia, mild thrombocytopenia, elevated creatinine and altered hepatic functions [35].

Some observations indicate its full grown status occurs within 14-18 days and that the silent incubation period alters the biochemical function of the vital internal organs of the host. Cohort studies conducted in China have observed few common issues among the Covid-19 infected patients.

Major clinical and biochemical observations include evidence of systemic virus dissemination beyond the respiratory tract, with virus detection reported in plasma and pleural effusion fluid, stools, urine and tears; with bacterial and fungal super infections. The other features reported include impaired interferon pathways, pancreatitis and hepatitis. Severe dehydration due to third space fluid loss and impaired immune response are also reported [10,11,14,15,18, 26, 28].

\section{a. Pathway of Covid-19 infection and disease progression}

The main entry point of the Covid-19 is the respiratory tract, where it first attaches to the mucus membrane of the nasal passage and sinus cavity. Covid-19 has a longer prodromal period of 14-18 days until lung invasion and a very slow phase of expression of symptoms compared with other coronaviruses infectious respiratory diseases $[16,26]$.

Once it reaches the lungs it enters the blood [28] stream and infects the most preferable sites in the human body. The coronaviruses are the common infection source of upper respiratory, gastrointestinal and central nervous system in humans and other mammals [31]. Coronaviruses are enveloped positive-stranded RNA viruses that replicate in the cytoplasm. To deliver their nucleocapsid into the host cell, they rely on the fusion of their envelope with the host cell membrane [34].

Human cell surface receptor, angiotensin converting enzyme 2 (ACE2), is recognized by the new coronavirus and serves as the access point into human cells [30]. The SARS-CoV-2 mediates entry in to human host cell using angiotensin-converting enzyme (ACE2) as a functional receptor [12]. The SARS-related coronaviruses are covered by spike glycoproteins that contain a variable 
receptor-binding domain (RBD). The 'spike glycoprotein S' of Covid-19 not only attach to the host cell surface but also fuse the viral and host cell membranes to allow the infection to start [30,34].

Virus Receptor Binding domain( RBD) binds to angiotensin-converting enzyme-2 (ACE-2) receptor found in the heart, lungs, kidneys, pancreas and gastrointestinal tract [13] thus facilitating viral entry into target cells. Other than the esophagus and the upper and stratified epithelial cells of the respiratory tract, ACE2 is also highly expressed in the digestive system. The intestinal epithelial cells and the absorptive enterocytes from ileum to colon are the most vulnerable sites [33].

It is also reported that ACE2 receptor is highly expressed on the cell membrane of pancreatic tissues [33]. Once the Viral RNA is released and enters the cytoplasm of the host cell, ACE2 receptor on the cell membrane becomes inactive and down regulated. This causes severe inflammation and vascular permeability. (Fig 1)

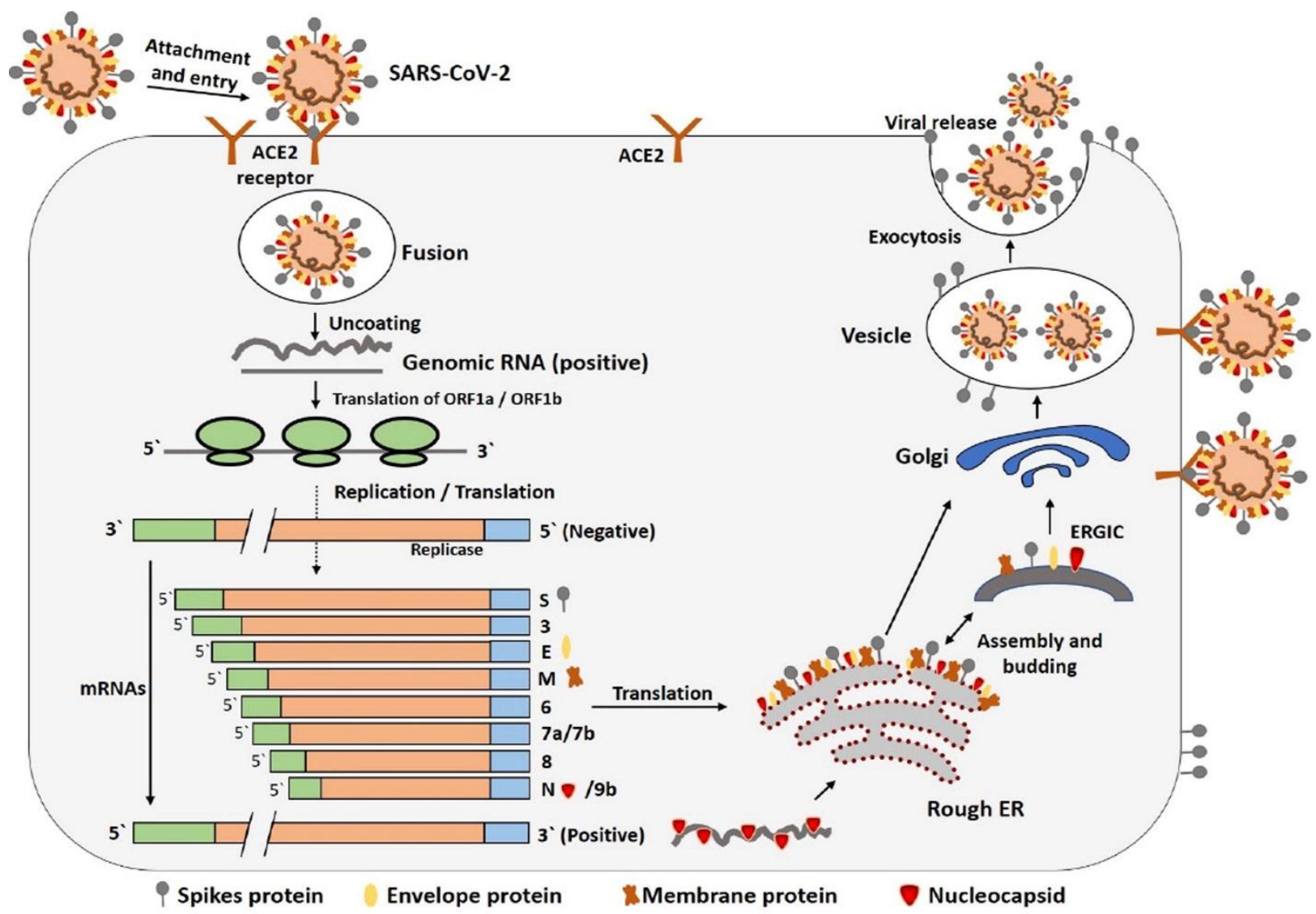

Fig 1: Receptor mediation between SARS-COV2 and ACE2 receptor of the host cell and replication process of the Covid-19 inside the human cell [36].

Adopted from Journal of Advanced Research, Volume 24, July 2020, Pages 91-98 https://doi.org/10.1016/j.jare.2020.03.005 
Evidently, absence of cough and dyspnea during first 14 days and detection of Covid-19 in stools [10] of patients with atypical abdominal symptoms [8,9] indicates SARS COV-2 Virus first site of major infection is not in the lungs. As it enters the blood stream Covid-19 immediately invade the host cell in the intestinal lining $[9,10,23]$ hepatocellular and pancreatic tissues. As the infection proceeds it creates a hemorrhagic condition within the internal muscular lining of the intestine. This alters three major digestive enzymes secretions from the pancreas namely amylase, peptidase and lipase indicating the changes to pancreatic functions. At this stage the liver develops hepatocellular changes.

This hypothesis is based on the fact that Covid-19 virus has a long incubation period of 1-14 days without any pathophysiological or symptomatic change of reaction in the lungs. The disease gradually progresses into lungs, kidney and heart after completing the 14-18 days of silent incubation. Globally, pancreatitis and hepatitis are clinically identified in Covid-19 infected patients. The severe dehydration and third space fluid loss becomes life threatening with sudden multiple organ failure [26].

Considering the above facts, attempts at early detection of Covid-19 should focus on the status of the gastrointestinal lining, profile of the pancreas and levels of the pancreatic enzymes. Hepatic change indicates the advance stages of the disease.

Clinical observation of the change in smell and taste of Covid-19 infected patients [19] during first 1-4 days suggest involvement of the vagal nerve and changes in the gastrointestinal secretions. Vagal nerve afferents control pancreatic enzyme secretion that results from the sight, smell, and taste of food. This suggest clear indication of alteration of pancreatic functions due the Covid-19 infection.

\section{b. Suggested biochemical and pathophysiological investigations for early detection}

The three enzymes that contribute to further damage are pancreatic amylase, lipases and trypsinogen secreted by the pancreas. Change in serum amylase levels could lead to thick mucus build up and ground-glass opacity that commonly seen in the lungs of Covid-19 infected patients $[37,38]$. Proteases digest proteins in the body, leading to destruction of red blood cells and blood profile.

Certain parameters such as measurement of Mean Platelet Volume (MPV) can be an early detection criteria as many Covid-19 infected patients exhibit thrombocytosis [8, 9] or thrombocytopenia at the time no abnormalities present in the chest X-Ray. (MPV) can be used as an indicator of platelet functions for thrombolytic inflammatory diseases [20]. Increased or decreased values of MPV is an indication of inflammatory condition of the pancreas [21, 22].

Serum Angiotensin level [24] is another marker for early detection. Angiotensin-converting enzyme-2 (ACE-2) and its effector peptide angiotensin II (Ang II) has been implicated in the pathogenesis of pancreatitis. This indicate of Covid-19 impact on the pancreas pointing damage and destruction of pancreatic cellular functions that leads to disease progression. 


\section{c. Covid-19 disease progression and recommendations}

This reveals the importance of investigating the clinical and biochemical changes to identify Covid-19 infection before disease progression. These changes are associated with the probable damage to the pancreatic function due to gastrointestinal cellular changes as a major site of Covid-19 infection. Cohort studies also revealed that the longest observed duration of viral shedding in a survivor is 37 days. Table 1

Table 1: clinical changes for early detection $[4,6,7,8,9,15,16,26,27,39]$

\begin{tabular}{|c|c|c|}
\hline No of Days & Symptoms & Covid-19 infection site \& damage \\
\hline $1-3$ & $\begin{array}{l}\text { Dry eyes } \\
\text { Glossy eyes with a yellow tint } \\
\text { (closed observation) }\end{array}$ & $\begin{array}{l}\text { Enter blood via respiration or eyes. Virus } \\
\text { occupy nasal cavity, sinus, lungs and saliva. }\end{array}$ \\
\hline $1-14$ & $\begin{array}{l}\text { No specific symptoms. } \\
\text { No fever or cough }\end{array}$ & $\begin{array}{l}\text { Slight enlargement of pancreas due to over } \\
\text { production of pancreatic enzymes. } \\
\text { Inflammation of the lungs and gastrointestinal } \\
\text { tract. Virus appears in stools }\end{array}$ \\
\hline $1-14$ & $\begin{array}{l}\text { Thrombocytosis observed } \\
\text { Thrombopenia observed } \\
\text { Lung } X \text { ray no abnormality }\end{array}$ & $\begin{array}{l}\text { No indication or symptoms of a respiratory } \\
\text { infection }\end{array}$ \\
\hline $1-14$ & $\begin{array}{l}\text { Some experience the losing of } \\
\text { smell and taste }\end{array}$ & $\begin{array}{l}\text { Impact on the Vagal nerve afferents control } \\
\text { pancreatic enzyme secretion that results from } \\
\text { the sight, smell, and taste of food. Also } \\
\text { indicate upper respiratory tract infection. }\end{array}$ \\
\hline $\begin{array}{l}14 \text { - } 18 \text { days } \\
\text { Symptomatic } \\
\text { period }\end{array}$ & $\begin{array}{l}\text { Fever average } 38.5 \mathrm{C} \\
\text { Sore throat } \\
\text { Dry cough } \\
\text { Shortness of breath, } \\
\text { Nasal congestion } \\
\text { Headache } \\
\text { Stomach pain and diarrhea } \\
\text { Severe dehydration }\end{array}$ & $\begin{array}{l}\text { As a protective mechanism mucus production } \\
\text { increases in the lungs. } \\
\text { Disease progressed rapidly indicating } \\
\text { bleeding in the inner muscle intestinal wall, } \\
\text { reduction in bicarbonates secretion from the } \\
\text { pancreas unable to neutralize digestion } \\
\text { enzymes. }\end{array}$ \\
\hline $23-25$ days & $\begin{array}{l}\text { Sepsis } \\
\text { Acute respiratory distress } \\
\text { syndrome (ARDS) }\end{array}$ & $\begin{array}{l}\text { Impact liver, kidneys and heart functions } \\
\text { Virus present in all the excretory organs and } \\
\text { blood }\end{array}$ \\
\hline 23 - 25 days & $\begin{array}{l}\text { Disease progression varies } \\
\text { according the severity of the } \\
\text { condition based with age, } \\
\text { underlying other health } \\
\text { condition. } \\
\text { Acute cardiac injury } \\
\text { Acute kidney injury } \\
\text { Secondary infections }\end{array}$ & $\begin{array}{l}\text { Covid-19 present in Urine, Blood, Stool, } \\
\text { Saliva, mucus, organs, breath }\end{array}$ \\
\hline
\end{tabular}




\begin{tabular}{|c|c|c|}
\hline 25 - 31 days & Death or Survival & Covid -19 continued to be contagious \\
\hline 37 days & If Survived & $\begin{array}{l}\text { Covid-19 completes the life cycle. Possibility } \\
\text { of detecting in the hair follicle and sweat. Viral } \\
\text { shedding lasts in stools for more than } 1 \text { month } \\
\text { after recovery [27]. }\end{array}$ \\
\hline
\end{tabular}

\section{d. Recommendations}

The following biochemical and physical investigations can be suggested to identify the early onset of the disease

Table 2: List of biochemical tests suggested to identify early onset $[20,21,22,24,29]$

\begin{tabular}{|l|l|}
\hline Mean Platelet Volume (MPV) & $\begin{array}{l}\text { Indicator of thrombocytic activity, has been } \\
\text { investigated in various proinflammatory and } \\
\text { prothrombotic clinical states. Positive correlation } \\
\text { between MPV and liver and pancreatic enzymes. }\end{array}$ \\
\hline Platelet Activation Factor (PAF) & $\begin{array}{l}\text { Serves as a primary mediator of inflammation in the } \\
\text { pathogenesis pancreas and PAF contributes to local } \\
\text { tissue damage and bleeding. }\end{array}$ \\
\hline Serum Amylase & $\begin{array}{l}\text { Inflammatory process associated with tissue damage } \\
\text { of pancreas }\end{array}$ \\
\hline Trypsin Activation Peptide (TAP) & $\begin{array}{l}\text { Inflammatory process associated with tissue damage } \\
\text { of pancreas }\end{array}$ \\
\hline Pancreatic Bicarbonate & $\begin{array}{l}\text { TAP activity increases early in the course of the } \\
\text { pancreatic changes and attains maximal value within } \\
24-48 \text { hours. }\end{array}$ \\
\hline $\begin{array}{l}\text { Vasodilator Intestinal Peptide } \\
\text { (VIP) }\end{array}$ & $\begin{array}{l}\text { Pancreatic secretion for acid balancing. May indicate } \\
\text { cellular changes in pancreas. }\end{array}$ \\
\hline Serum Angiotensin Level & $\begin{array}{l}\text { Concentration of this peptide (VIP) of ACE2 pathway } \\
\text { determine specially with diarrhea patients for } \\
\text { intestinal cellular damage. }\end{array}$ \\
\hline $\begin{array}{l}\text { Affector peptide of Angiotensin II for pathogenesis of } \\
\text { pancreas }\end{array}$ \\
\hline tomagraphy (CECT)
\end{tabular}


Early identification of Covid-19 asymptomatic individuals is the biggest challenge faced globally. This study recommends a longer quarantine period of $18-21$ days instead of 14 days. Furthermore due to further viral shedding of survived individuals, actual full recovery period should extend up to 37 days. Shedding can be further monitored by testing stools, sweat and hair follicles. Another major way of disease spread is via excretion of urine and faeces. Proper hygiene practice and sanitary issues in poor countries need attention as Covid-19 virus indicates prolong survival period in the human excretory system.

Above biochemical investigations first should focus on families with infected individuals. Individuals with underline health issues and older generation need priority of testing.

\section{Conclusion}

We believe that these findings will contribute to a better understanding of the actual process of the disease progression and will contribute to advances in the implementation of more efficient clinical treatment and infection control strategies.

This review has compiled many data reported in literature and highlighted the alternative diagnostic pathways to identify the Covid-19 infection. Suggested clinical and biochemical parameters would be useful for early diagnosis of both asymptomatic and symptomatic individuals infected with SAR CoV-2 virus.

The main organ effected by Covid-19 are identified as pancreas and Intestine. We believe investigation of the pancreatic functions are the fastest and shortest way to identify the Covid-19 deadly virus.

Due to unavailability of actual sample testing with infected patients, we present this argument as an awareness of possible approach for a cure. This opens doors with a new concept to tackle the New Corona Covid-19 virus before full grown level of the disease for easy management and to stop the spread in the worldwide scale.

\section{Acknowledgments}

We acknowledge Professor W.S.Sulochana Wijesundera, Department of Biochemistry \& Molecular Biology, Faculty of Medicine, University of Colombo, Sri Lanka for the support and guidance.

Professor Saroj Jayasinghe, Professor of Medicine, Department of Clinical Medicine, Faculty of Medicine, University of Colombo, Sri Lanka for valuable comments.

Financial support: none related to the content of this manuscript.

Conflict of interests: none related to the content of this manuscript. 


\section{References}

1. Lu H, Stratton CW, Tang YW., "Outbreak of pneumonia of unknown etiology in Wuhan China: the mystery and the miracle", J Med Virol. 92(4):401-402, 2020

2. Hui DS, I Azhar E, Madani TA, et al., "The continuing 2019-nCoV epidemic threat of novel coronaviruses to global health: the latest 2019 novel coronavirus outbreak in Wuhan, China", Int J Infect Dis., 91:264-266, 2020

3. Wuhan Municipal Health Commission. Report of novel coronavirus-infected pneumonia in China. Published January 20, 2020. Accessed January 31, 2020. http://wjw.wuhan.gov.cn/front/web/showDetail/2020012009077

4. Paules $\mathrm{Cl}$, Marston HD, Fauci AS., "Coronavirus infections-more than just the common cold", JAMA. 323(8):707-708, 2020

5. Wuhan Municipal Health Commission. Report of clustering pneumonia of unknown etiology in Wuhan City. Published December 31, 2019. Accessed January 31, 2020. http://wjw.wuhan.gov.cn/front/web/showDetail/2019123108989

6. Chan JF-W, Yuan S, Kok K-H, et al., "A familial cluster of pneumonia associated with the 2019 novel coronavirus indicating person-to-person transmission: a study of a family cluster", Lancet. S0140-6736(20)30154-9., 2020

7. Phan LT, Nguyen TV, Luong QC, et al., "Importation and human-to-human transmission of a novel coronavirus in Vietnam", N Engl J Med., 382(9):872-874, 2020

8. Chang D et al. "Epidemiologic and clinical characteristics of novel coronavirus infections involving 13 patients outside Wuhan, China". JAMA,323(11):1092-1093., 2020

9. Wang D et al., "Clinical characteristics of 138 hospitalized patients with 2019 novel coronavirus-infected pneumonia in Wuhan, China". JAMA 323(11):1061-1069.,2020

10. Zhang H, Kang ZJ, Gong HY, et al., "The digestive system is a potential route of 2019 nCoV infection: a bioinformatics analysis based on single-cell transcriptomes." Preprint. Posted online January 31, 2020. bioRxiv 927806.

11. Carlos del Rio, MD Wang D et al. "2019 Novel Coronavirus: New Clinical Insights" JAMA 2020 Feb 7 Chang D et al. JAMA 2020 Feb 7

12. Alexandra C. Walls, Young-Jun Park, M. Alexandra Tortorici, Abigail Wall, Andrew T. McGuire, David Veesler, "Structure, function and antigenicity of the SARS-CoV-2 spike glycoprotein", Cell, 180,1-12, 2020

13. Ksiazek, T.G.; Erdman, D.; Goldsmith, C.S.; Zaki, S.R.; Peret, T.; Emery, S.; Tong, S.; Urbani, C.; Comer, J.A.; Lim, W.; et al., "A Novel Coronavirus Associated with Severe Acute Respiratory Syndrome”. N. Engl. J. Med. 348, 1953-1966., 2003

14. Zhu $\mathrm{N}$ et al. " A novel coronavirus from patients with pneumonia in China, 2019," N Engl J Med , 382 (8), 727-733, 2020 
15. Huang $\mathrm{C}$ et al., "Clinical features of patients infected with 2019 novel coronavirus in Wuhan, China,” Lancet, 395 (10223), 497-506, 2020

16. Bai, Y.; Yao, L.; Wei, T.; Tian, F.; Jin, D.-Y.; Chen, L.; Wang, M., "Presumed Asymptomatic Carrier Transmission of COVID-19”. JAMA 2020. Published online February 21, 2020. doi:10.1001/jama.2020.2565

17. Rothe, C.; Schunk, M.; Sothmann, P.; Bretzel, G.; Froeschl, G.; Wallrauch, C.; Zimmer, T.; Thiel, V.; Janke, C.; Guggemos, W.; et al. "Transmission of 2019-nCoV Infection from an Asymptomatic Contact in Germany”. N. Engl. J. Med., 382:970-971, 2020.

18. Zou, L.; Ruan, F.; Huang, M.; Liang, L.; Huang, H.; Hong, Z.; Yu, J.; Kang, M.; Song, Y.; Xia, J.; et al. SARS-CoV-2 "Viral Load in Upper Respiratory Specimens of Infected Patients". N. Engl. J. Med., 382:1177-1179, 2020

19. Prof Claire Hopkins, BMBCh, MA FRCS(ORLHNS) DM(Oxon) President of the British Rhinological Society Professor of Rhinology, King's College London Consultant ENT Surgeon, Guy's and St Thomas' Hospitals Prof Nirmal Kumar, President of ENT UK "Loss of sense of smell as marker of COVID-19 infection"

20. Gasparyan AY, Ayvazyan L, Mikhailidis DP, Kitas GD. “Mean platelet volume: a link between thrombosis and inflammation"? Curr Pharm Des ,17:47-58(12), 2011

21. Kerekes L, Arkossy P, Altorjay I, Huszka M, Kappelmayer J, Toth P, Szentkereszty Z, Sapy P. "Evaluation of hemostatic changes and blood antioxidant capacity in acute and chronic pancreatitis". Hepatogastroenterology. ;48:1746-1749, 2001

22. Lippi G, Valentino M, Cervellin G. "Laboratory diagnosis of acute pancreatitis: in search of the Holy Grail”. Crit Rev Clin Lab Sci.;49:18-31. 2012

23. Wong $\mathrm{SH}^{1,2}$, Lui RN ${ }^{1,2}$, Sung JJ1,2. "Covid-19 and the Digestive System". J Gastroenterol Hepatol. 2020 Mar 25. doi: 10.1111/jgh.15047. [Epub ahead of print]

24. Liu R ${ }^{1}$, Qi H, Wang J, Wang Y, Cui L, Wen Y, Yin C. “Angiotensinconverting enzyme (ACE and ACE2) imbalance correlates with the severity of ceruleininduced acute pancreatitis in mice". Exp Physiol. ;99(4):651-63., 2014

25. KEITH GRIFFITH FOR DAILYMAIL.COM PUBLISHED: 05:22 BST, 29 March 2020 | UPDATED: 11:31 BST, 29 March 2020

https://www.dailymail.co.uk/news/article-8164235/US-coronavirus-Map-shows-eightstrains-raced-world.html

26. Zhou $F^{1}$, $Y u T^{2}$, Du $R^{3}$, Fan $G^{4}$, Liu $Y^{2}$, Liu $Z^{1}$, Xiang $J^{5}$, Wang $Y^{6}$, Song $B^{2}$, Gu $X^{4}$, Guan $\mathrm{L}^{3}$, Wei $\mathrm{Y}^{2}$, $\mathrm{Li} \mathrm{H}^{1}$, Wu $\mathrm{X}^{7}, \mathrm{Xu} \mathrm{J}^{8}$, Tu $\mathrm{S}^{2}$, Zhang $\mathrm{Y}^{1}$, Chen $\mathrm{H}^{9}$, Cao $\mathrm{B}^{10}$. "Clinical course and risk factors for mortality of adult inpatients with COVID-19 in Wuhan, China: a retrospective cohort study". Lancet. 28;395(10229):1054-1062.,2020 
27. Yuan Tian ${ }^{1}$, Long Rong ${ }^{1}$, Weidong Nian ${ }^{1}$, Yan He ${ }^{1}$ "Review Article: Gastrointestinal Features in COVID-19 and the Possibility of Faecal Transmission." AP\&T Alimentary Phamacology \& Therapeutics. DOI:10.1111/apt.15731. 26 March 2020

28. Rajesh T. Gandhi, MD reviewing Zhu N et al." 2019 Novel Coronavirus: First Reports Published" N Engl J Med 2020 Jan 24 Huang C et al. Lancet 2020 Jan 24 Chan JF-W et al. Lancet 2020 Jan 24

29. Akbal E, Demirci S, Kocak E, Koklu S, Basar O, Tuna Y. "Alterations of platelet function and coagulation parameters during acute pancreatitis". Blood Coagul Fibrinolysis. 24:243-246.,2013

30. B. Robson; Computers and viral diseases. "Preliminary bioinformatics studies on the design of a synthetic vaccine and a preventative peptidomimetic antagonist against the SARS-CoV-2 (2019-nCoV, COVID-19) coronavirus" Comput Biol Med., 119,103670, 2020

31. Perlman S, Netland J. "Coronaviruses post-SARS: update on replication and 32 pathogenesis". Nat Rev Microbiol. 7: 439-50.,2009

32. Hao Zhang, Zijian Kang, Haiyi Gong, Da Xu, Jing Wang, Zifu Li, Xingang Cui, Jianru Xiao, Tong Meng, Wang Zhou, Jianmin Liu, Huji Xu;" The digestive system is a potential route of 2019-nCov infection: a bioinformatics analysis based on single-cell transcriptomes" bioRxiv doi: https://doi.org/10.1101/2020.01.30.927806

33. Heleia Roca-Ho, ${ }^{1, \dagger}$ Marta Riera, ${ }^{1, \dagger}$ Vanesa Palau, ${ }^{1}$ Julio Pascual,${ }^{1,2}$ and Maria Jose Soler ${ }^{1,2}$ Characterization of ACE and ACE2 Expression within Different Organs of the NOD Mouse Int J Mol Sci. 18(3): 563.,

34. Sandrine Belouzard 1, Jean K. Millet 2 , Beth N. Licitra 2 and Gary R. Whittaker 2,* "Mechanisms of Coronavirus Cell Entry Mediated by the Viral Spike Protein", Viruses 4, 1011-1033; 2012

35 Michelle L. Holshue, M.P.H., Chas DeBolt, M.P.H., Scott Lindquist, M.D., Kathy H. Lofy, M.D., John Wiesman, Dr.P.H., Hollianne Bruce, M.P.H., Christopher Spitters, M.D., Keith Ericson, P.A.-C., Sara Wilkerson, M.N., Ahmet Tural, M.D., George Diaz, M.D., Amanda Cohn, M.D., et al., for the Washington State 2019-nCoV Case Investigation Team "First Case of 2019 Novel Coronavirus in the United States" N Engl J Med 382:929-936, 2020

36. Muhammad AdnanShereen ${ }^{\text {ab1 }}$ SulimanKhan ${ }^{\text {a1 }}$ AbeerKazmicNadiaBashira RabeeaSiddique ${ }^{\mathrm{a}}$ "COVID-19 infection: Origin, transmission, and characteristics of human coronaviruses", Journal of Advanced Research, 24: 91-98, 2020

37. M R Kramer ${ }^{1}$, M J Saldana, R J Cepero, A E Pitchenik, "High Amylase Levels in Neoplasm-Related Pleural Effusion", Ann Intern Med, 110 (7), 567-9 ,1989 
38. M Otsuki, H Yuu, M Maeda, S Saeki, T Yamasaki, "Amylase in the Lung", Cancer, 39 (4), 1656-63, 1977

39. Hao Xu, Liang Zhong, Jiaxin Deng, Jiakuan Peng, Hongxia Dan, Xin Zeng, Taiwen Li., Qianming Chen, High expression of ACE2 receptor of 2019-nCoV on the epithelial cells of oral mucosa, International Journal of Oral Science 12: 8, 2020 